\title{
Paraganglioma of the cauda equina - Case Report and Literature Review
}

\section{Paraganglioma de cauda equina - Relato de caso e Revisão da Literatura}

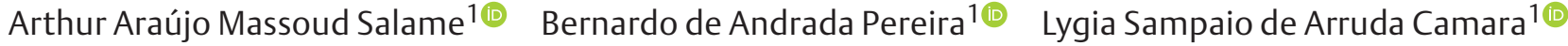 \\ logo Henrique de Oliveira Araújo ${ }^{1}$ Filipe Moreira de Almeida Pinheiro ${ }^{10}$ Estevão Cardoso Carvalho ${ }^{10}$ \\ Francisco Weldes Brito das Neves ${ }^{10}$ José Alvaro Bastos Pinheiro ${ }^{10}$
}

\author{
${ }^{1}$ Departament of Neurosurgery, Hospital Municipal Salgado Filho, Rio \\ de Janeiro, RJ, Brazil \\ Arq Bras Neurocir
}

Address for correspondence Arthur Araújo Massoud Salame, MD, Departamento de Neurocirurgia, Hospital Municipal Salgado Filho. Rua Arquias Cordeiro, 370, Méier, Rio de Janeiro - RJ, 20770-000, Brasil (e-mail: arthursalame@hotmail.com).

\begin{abstract}
Keywords

- paraganglioma

- cauda equina

- spinal tumors

\section{Resumo}

\section{Palavras-chave}

- paraganglioma

- cauda equina

- tumores espinhais

Paragangliomas of the cauda equina are tumors of rare incidence, with $\sim 220$ cases described in the world literature. They are benign lesions, grade I by the World Health Organization (WHO), whose definitive diagnosis can only be made by immunohistochemical analysis. Its neuroendocrine nature is evidenced by the presence of chromogranin. The relevance of reporting this case is because paragangliomas of the cauda equina should be included among the differential diagnoses of intradural and extramedullary tumors, and especially because they can cause perioperative and intraoperative hypertensive crises by adrenergic discharge.

The present study presents the case of a 36-year-old male patient diagnosed with a lumbar spine tumor located in the central spinal canal that presented as cauda equina syndrome involving 4 months of bilateral sciatica, paraparesis, urinary and fecal retention. The diagnosis of paraganglioma was confirmed by immunohistochemical positivity for chromogranin after microsurgical resection of the tumor.

Paragangliomas da cauda equina são tumores de incidência rara, com $\sim 220$ casos descritos na literatura mundial. São lesões benignas, grau 1 pela Organização Mundial da Saúde (OMS), cujo diagnóstico definitivo apenas pode ser feito pela análise imunohistoquímica, onde se evidencia a natureza neuroendócrina dada especialmente pela presença de cromogranina. O presente relato de caso se torna importante porque este deve ser considerado entre os diagnósticos diferenciais de tumores intradurais e extramedulares, e porque há trabalhos na literatura descrevendo crises hipertensivas durante a ressecção da lesão devidas a descarga adrenérgica.
\end{abstract}

received

May 12,2020

accepted

March 9, 2021
DOI https://doi.org/ 10.1055/s-0041-1731011. ISSN 0103-5355.

\footnotetext{
(c) 2022. Sociedade Brasileira de Neurocirurgia. All rights reserved. This is an open access article published by Thieme under the terms of the Creative Commons Attribution-NonDerivative-NonCommercial-License, permitting copying and reproduction so long as the original work is given appropriate credit. Contents may not be used for commercial purposes, or adapted, remixed, transformed or built upon. (https://creativecommons.org/ licenses/by-nc-nd/4.0/)

Thieme Revinter Publicações Ltda., Rua do Matoso 170, Rio de Janeiro, RJ, CEP 20270-135, Brazil
} 
O presente estudo apresenta o caso de um paciente masculino de 36 anos diagnosticado com tumor na coluna lombar localizado no canal medular, que cursou com síndrome de cauda equina, com 4 meses de lombociatalgia bilateral, evoluindo à paraparesia, retenção urinária e fecal. Após microcirurgia para ressecção tumoral, o diagnóstico de paraganglioma só foi confirmado através da imunohistoquímica, com positividade para cromogranina.

\section{Introduction}

Paragangliomas of the cauda equina region are a rare incidence tumor, with $\sim 220$ total cases described in the world literature, and they correspond to $\sim 3.5 \%$ of the tumors in this region. ${ }^{1,2}$ The first case was described in 1970 initially as a secretory ependymoma. ${ }^{3}$ From that date on, between 4 and 8 cases are usually described annually, with greater evidence since the eighties due to the development of more accurate immunohistochemistry techniques and the use of magnetic resonance imaging (MRI). ${ }^{4}$

Paragangliomas are neuroendocrine tumors classified as grade I by the World Health Organization (WHO) grading system, have a slow-growing behavior, and arise from the paraganglia cells (group of neuroepithelial cells). There are two groups of paraganglia cells: one composed by adrenal medulla cells and the other composed by the extra-adrenal paraganglia cells. ${ }^{5}$

The term pheochromocytoma is used for tumors that arise from the adrenal medulla, while paraganglioma is used for tumors from the extra-adrenal paraganglia. Paragangliomas may occur in any part of the body, but tumors of the carotid body and of the glomus jugulare constitute $>90 \%$ of the reported paragangliomas. ${ }^{2}$
An accurate preoperative diagnosis of paraganglioma is very difficult to achieve. A definitive diagnosis depends basically on the pathological examination and, especially, of an immunohistochemical study in order to differentiate it from other intradural extramedullary lesions, which should always be considered for differential diagnosis, that is, ependymomas, schwannomas, meningiomas, metastatic tumors, hemangioblastomas, and lipomas. ${ }^{6}$

The goals of the present study are to report a case of a patient with a paraganglioma of the cauda equina region and to perform an extensive literature review on the topic.

\section{Case Report}

A 36-year-old male was admitted at the hospital with complaints of bilateral low back pain of 4 months of evolution associated with progressive paraparesis - muscle strength grade 4 on the lower limbs, proximal and distal. The patient also had urinary and fecal retention that were progressively worsening. An MRI of the lumbar spine was performed and evidenced an intradural expansive lesion at the level of the $\mathrm{L} 2$ vertebrae with an estimated dimension of $3.0 \times 2.0 \mathrm{~cm}$ (-Fig. 1).

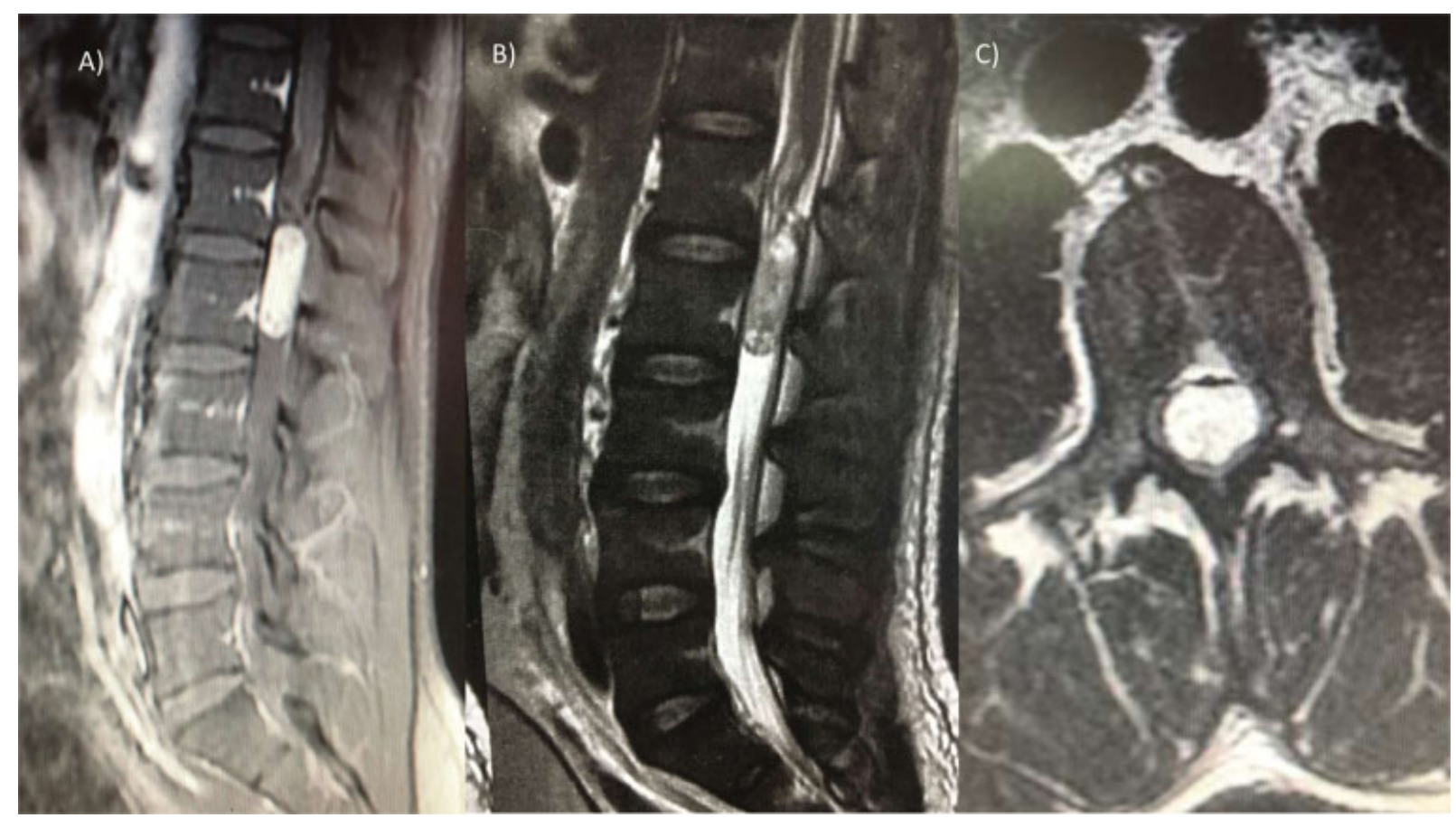

Fig. 1 Magnetic resonance imaging of the lumbar spine showing an intradural mass at L2. (A) T1 weighted with contrast sagittal view. (B) T2 weighted without contrast sagittal view. (C) T1 weighted with contrast axial view. 


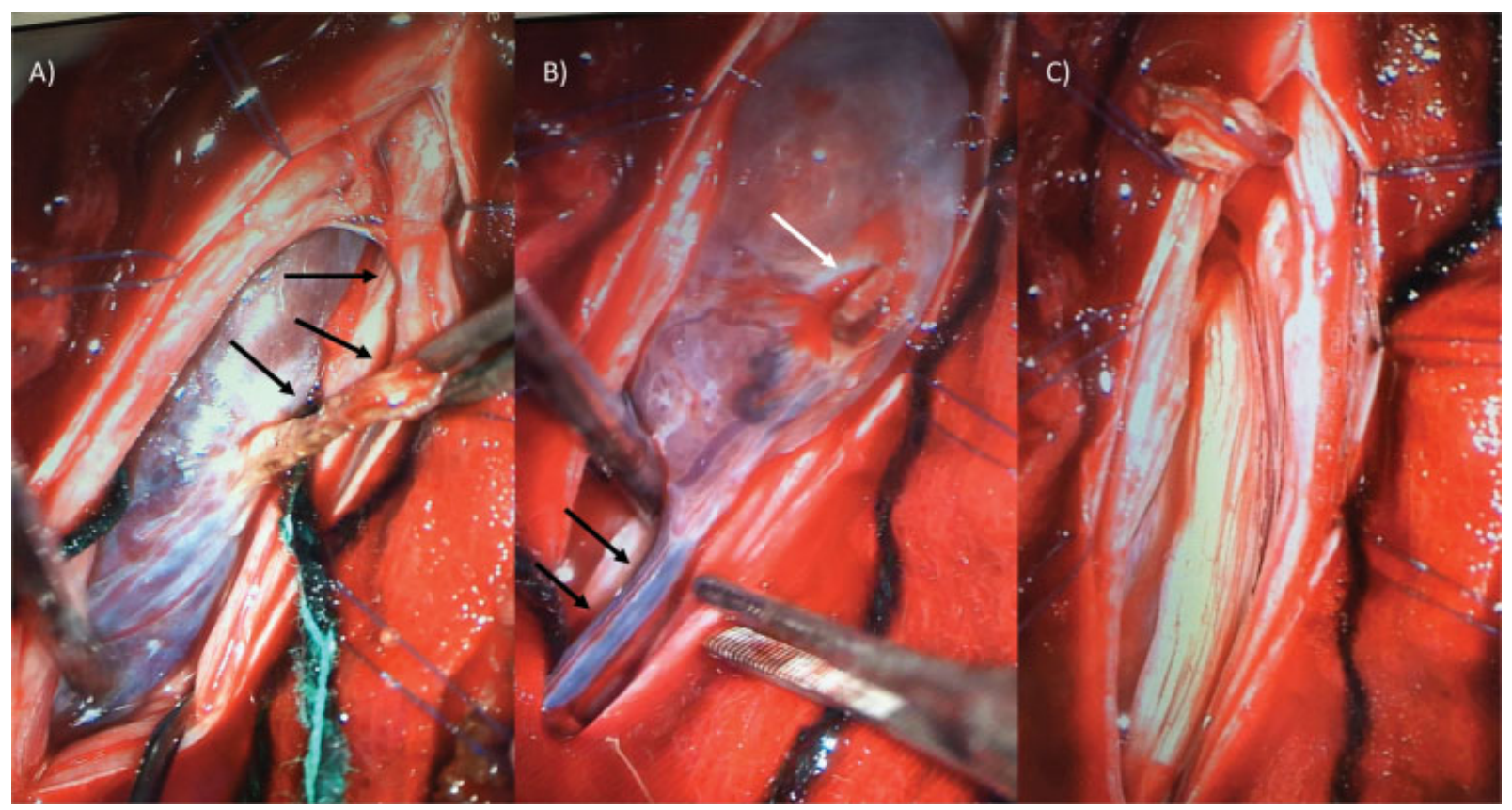

Fig. 2 Intraoperative images of the resection of the paraganglioma of the cauda equina. (A) Paraganglioma compressing the nerve roots of the cauda equina, black arrows evidence the proximal portion of the filum terminale after dissection prepared to be sectioned. (B) After sectioning the proximal portion of the filum terminale (white arrow), the distal portion is under dissection and preparation for coagulation and sectioning (black arrows). (C) Nerve roots of the cauda equina free from compression after tumor removal.

The patient underwent complete microsurgical resection of the tumor which arises on the filum terminale, under general anesthesia. The lumbar and sacral nerve roots were preserved. Intraoperative images are exhibited on - Fig. 2. The completely excised tumor is exhibited on $\boldsymbol{\sim}$ Fig. 3. Neuromonitoring was not available.

An anatomopathological macroscopic examination showed a well-defined encapsulated red lesion measuring $3.0 \times 1.5 \times 1.5 \mathrm{~cm}$, with a grayish smooth surface, elastic consistency, and small cystic cavities observed after slicing. The microscopic examination was suggestive of myxopapillary ependymoma under hematoxylin and eosin.

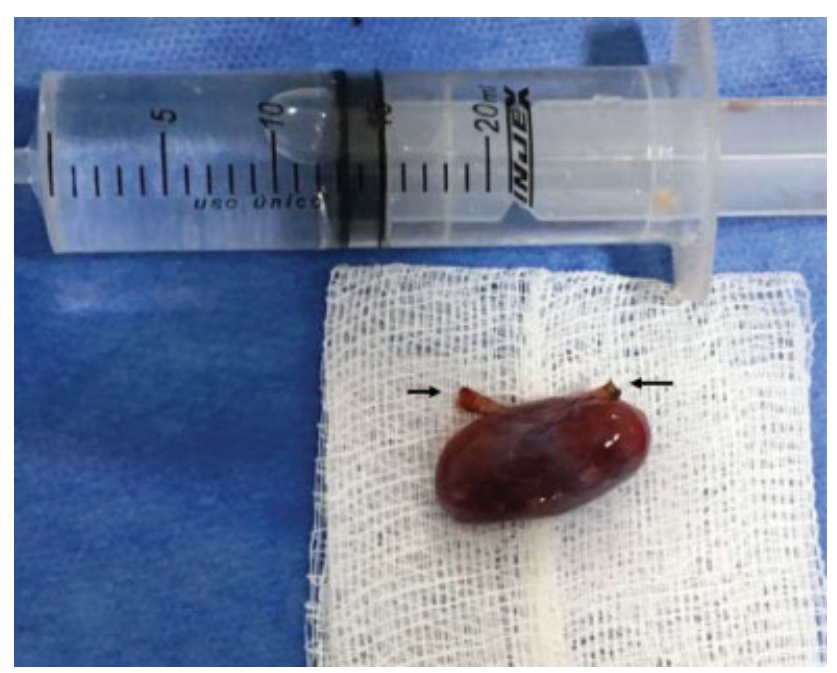

Fig. 3 Macroscopic aspect of completely excised paraganglioma. The two black arrows evidence, respectively, the proximal and distal remains of the filum terminale.
However, immunohistochemistry evidenced a paraganglioma with positivity for chromogranin and negativity for glial fibrillary acidic protein (GFAP), S100, and AE1/AE3

\section{(-Fig. 4).}

The patient was discharged at the $4^{\text {th }}$ postoperative day with complete improvement of motor function and partial improvement in sphincter disorders. There are no signs of recurrence in 2 years of follow-up (-Fig. 5).

\section{Discussion}

The low incidence of this type of tumor makes this report more important in the literature. Although rare, these tumors may cause systemic manifestations because they have the biochemical feature of producing and storing biogenic amines, as well as the potential to produce peptide hormones (adrenaline, noradrenaline, and dopamine). ${ }^{5}$

Even though they are unusual, there are reported cases of hormonal activity with abnormal urine noradrenaline concentration and features of vasomotor amine syndrome. The

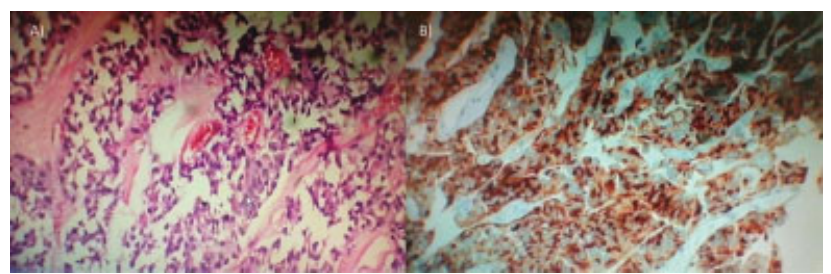

Fig. 4 Histology: (A) Hematoxylin and eosin, nest of tumor cell, consisting of a round small tumor cell, separated by a fine vascular network, known as a "Zellballen"pattern. (B) Immunohistochemical analysis positive for chromogranin. 


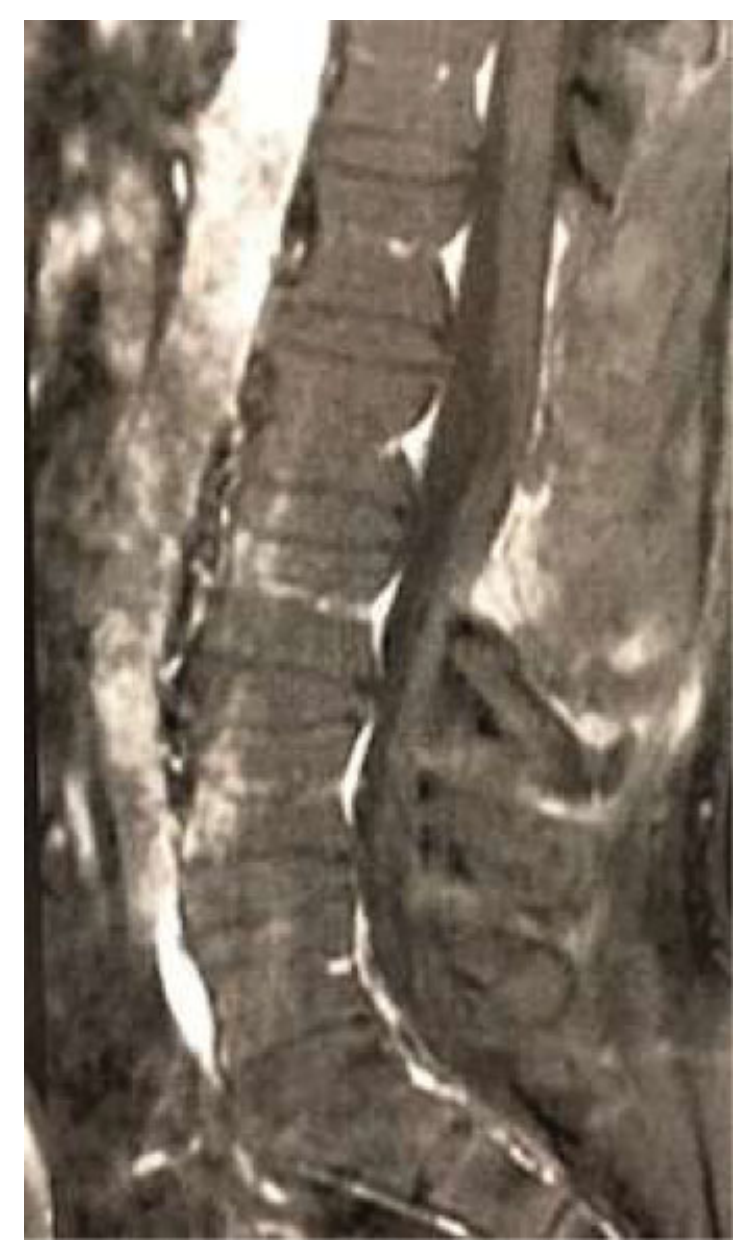

Fig. 5 Two-year postoperative magnetic resonance imaging with no evidence of recurrence.

limited occurrence of paroxysmal hyperadrenergic states in spinal paragangliomas may have two reasons: first, the incapacity of the tumor cells to secrete stored substances, or second, the incapacity of these substances to cause a clinical syndrome. ${ }^{7}$

The main symptoms caused by this type of tumors are low back pain, which may be present in $90 \%$ of the cases, and sciatica, described in at least $72 \%$. Motor or sensory deficits are detected in $35 \%$ of the cases while sphincter and erectile dysfunctions were reported, respectively, in 14 and $1.2 \%$ of the patients. ${ }^{8,9}$

The group of patients at risk described on the literature are within the age range between 12 and 77 years old, with a peak incidence on the $4^{\text {th }}$ and $5^{\text {th }}$ decades of life, with a male predominance. The male to female ratio is $1.54 .8,10$

Magnetic resonance imaging is the gold standard exam, but the neuroradiological features of these lesions are not specific and demonstrate only the alternatives in the differential diagnosis. ${ }^{11}$ There are no pathognomonic findings for cauda equina paragangliomas. The lesion is usually hypo or isointense on T1 sequences compared with the conus medullaris, whereas it is hyperintense on $\mathrm{T} 2$ sequences and may be heterogeneous due to subacute blood clot. ${ }^{11}$

Paragangliomas happen mostly sporadically, but familial forms can also occur in an autosomal dominant trait in $~ 1 \%$ of the cases. However, in the cauda equina region, inheritance in these types of tumors has never been reported. ${ }^{12}$ The lesions are encapsulated in $80 \%$ of cases, while invasion can occur in $15 \%$. The size of the tumor usually varies from 1.5 to $13 \mathrm{~cm} .{ }^{8,13}$ A complete resection is the ultimate goal of surgery. Total excision is feasible in $90 \%$ of the patients. The tumor is attached to the filum terminale in $85 \%$ of the cases, either directly or by a vascular pedicle. .,13-15 $^{-15}$

The step-by-step of the surgery performed on the aforementioned case is in line with the literature: prone position on surgical table, posterior lower back midline incision, laminectomy of the L2 and of the lower half of the L1, and opening of the dura mater followed by visualization of the nerve roots of the cauda equina. After careful arachnoid microdissection, the nerve roots were separated and a bright red mass was identified on the body of the filum terminale, with a large tortuous exuberant vessel coursing longitudinally on its wall. Bipolar coagulation of the referred vessel was performed, followed by coagulation of the proximal and distal portion of the filum terminale. The filum was proximally and distally sectioned and the tumor removed en bloc to prevent extensive bleeding and subarachnoid dissemination of the tumor. ${ }^{16}$

In cases in which only subtotal removal was achieved, recurrence will happen in $\sim 10 \%$ in a period of 1 year. Recurrence does not necessarily mean malignancy, but a sign of suboptimal resection and regrowth. Encapsulated tumors are favorable to complete removal and have greater chance of cure. The options in cases of recurrence include reoperation and radiation therapy, and each case should be judged individually. ${ }^{8,17}$

\section{Limitations}

No immunohistochemical differentiation between chromogranin A or B was made in the current case. Synaptophysin was not available.

\section{Conclusion}

Paragangliomas of the cauda equina are rare tumors whose diagnosis is only confirmed by immunohistochemical analysis. They must be included among the differential diagnoses of intradural and extramedullary spinal tumors. Case reports become more important because, in addition to these tumors being in an atypical location, there are studies in the literature describing hypertensive crises during resection of the lesion due to adrenergic discharge.

\section{Conflict of Interests}

The authors have no conflict of interests to declare.

\section{References}

1 Ardon H, Plets C, Sciot R, Calenbergh FV. Paraganglioma of the cauda equina region: A report of three cases. Surg Neurol Int 2011;2:96-99

2 Miliaras GC, Kyritsis AP, Polyzoidis KS. Cauda equina paraganglioma: a review. J Neurooncol 2003;65(02):177-190 
3 Miller CA, Torack RM. Secretory ependymoma of the filum terminale. Acta Neuropathol 1970;15(03):240-250

4 Kliewer KE, Cochran AJ. A review of the histology, ultrastructure, immunohistology, and molecular biology of extra-adrenal paragangliomas. Arch Pathol Lab Med 1989;113(11):1209-1218

5 Gelabert-González M. Paragangliomas of the lumbar region. Report of two cases and review of the literature. J Neurosurg Spine 2005;2(03):354-365

6 Levy RA. Paraganglioma of the filum terminale: MR findings. AJR Am J Roentgenol 1993;160(04):851-852

7 Corinaldesi R, Novegno F, Giovenali P, Lunardi T, Floris R, Lunardi P. Paraganglioma of the cauda equina region. Spine J 2015;15(03): e1-e8

8 Sonneland PRL, Scheithauer BW, LeChago J, Crawford BG, Onofrio BM. Paraganglioma of the cauda equina region. Clinicopathologic study of 31 cases with special reference to immunocytology and ultrastructure. Cancer 1986;58(08):1720-1735

9 Horoupian DS, Kerson LA, Sainotz H, Valsamis M. Paraganglioma of cauda equina. Clinicopathologic and ultrastructural studies of an unusual case. Cancer 1974;33(05):1337-1348
10 Park DH, Park YK, Oh JI, et al. Oncocytic paraganglioma of the cauda equina in a child. Case report and review of the literature. Pediatr Neurosurg 2002;36(05):260-265

11 Araki Y, Ishida T, Ootani M, et al. MRI of paraganglioma of the cauda equina. Neuroradiology 1993;35(03):232-233

12 Masuoka J, Brandner S, Paulus W, et al. Germline SDHD mutation in paraganglioma of the spinal cord. Oncogene 2001;20(36):5084-5086

13 Wolansky LJ, Stewart VA, Pramanik BK, et al. Giant paraganglioma of the cauda equina in adolescence: magnetic resonance imaging demonstration. J Neuroimaging 1996;6(01):54-56

14 Taxy JB. Paraganglioma of the cauda equina. Report of a rare tumor. Cancer 1983;51(10):1904-1906

15 Lagacé R, Delage C, Gagné F Paraganglioma of the filum terminale. Can J Neurol Sci 1978;5(02):257-260

16 Yang C, Li G, Fang J, et al. Clinical characteristics and surgical outcomes of primary spinal paragangliomas. J Neurooncol 2015; 122(03):539-547

17 Iliya AR, Davis RP, Seidman RJ. Paraganglioma of the cauda equina: case report with magnetic resonance imaging description. Surg Neurol 1991;35(05):366-367 